\title{
Novel Synthesis of Dienones and Enones from Propargyl Alcohols and Allyl Alcohols with 2,2-Dimethoxypropane:
}

\section{Synthesis of Ionone and Irone}

\author{
Toshinobu Ishinara,* Takeshi Kitahara and Masanao Matsui \\ The Institute of Physical and Chemical Research, Wako-shi, Saitama \\ * Research Fellow from the Naoetsu Research Laboratory of Shin-etsu Chemical \\ Industry Co., Nakakubiki, Nïgata
}

Received September 13, 1973

\begin{abstract}
A new synthetic procedure for dienone derivatives, i.e., ionone and irone, is described. The key step is the pyrolytic rearrangement of allyl alcohols and 2,2-dimethoxypropane in the presence of an acid anhydride and phosphoric acid.
\end{abstract}

Syntheses of dienones, ${ }^{11}$ enones ${ }^{2}$ and enesters $^{3)}$ by rearrangement of an allyl vinyl ether (i.e., Claisen-Cope type reaction) have already been achieved by many investigators. Developments in this field have been summarized in a detailed review. ${ }^{4}$ In the perfumery field, an efficient method of synthesis of these enones is desired, because many odor components such as ionones, irone, damascone etc., contain dienone or enone groups. We wish to describe a novel synthesis of enones and dienones, starting from allyl alcohols and acetylenic carbinols with 2,2dimethoxypropane in the presence of acetic anhydride and phosphoric acid at $130 \sim 200^{\circ} \mathrm{C}$ for $15 \sim 24 \mathrm{hr}$.

$$
\begin{aligned}
& \mathrm{R}_{2}{ }^{\mathrm{R}} \backslash \mathrm{C}_{\mathrm{C} \equiv \mathrm{CH}}^{\mathrm{OH}}+\underset{\mathrm{H}_{3} \mathrm{C}}{\mathrm{H}_{3} \mathrm{C}} \overbrace{\mathrm{OCH}_{3}}^{\mathrm{OCH}_{3}} \frac{\mathrm{Ac}_{2} \mathrm{O}}{\mathrm{H}_{3} \mathrm{PO}_{4}} \\
& \text { I } \\
& \mathrm{R}_{1} \backslash \mathrm{C}=\mathrm{CHCH}=\stackrel{\mathrm{O}}{\stackrel{\mathrm{CHCCH}}{\prime}} \\
& \text { II } \\
& \mathrm{R}_{1}, \mathrm{R}_{2}=\text { Alkyl or } \mathrm{H}
\end{aligned}
$$

In the synthesis of dienones by this method the reaction proceeded smoothly and dienones (II) were isolated as almost the sole product in moderate yields $(55 \sim 65 \%)$.

In the case of enone synthesis, however,<smiles>[R4]C(=C[CH2+])C([R])([R])O</smiles>

III

$$
\begin{gathered}
\mathrm{R}_{1} \backslash \mathrm{C}=\mathrm{C}\left(\mathrm{R}_{3}\right) \mathrm{CH}_{2} \mathrm{CH}_{2} \mathrm{CCH}_{3} \\
\mathrm{IV} \\
+\stackrel{\mathrm{R}}{\mathrm{R}_{2} \backslash \mathrm{C}=\mathrm{C}\left(\mathrm{R}_{3}\right) \mathrm{CH}_{2} \mathrm{OAC}} \\
+\mathrm{R}_{2} \\
{\left[\begin{array}{l}
\mathrm{R}_{1} \backslash \mathrm{C}=\mathrm{C}\left(\mathrm{R}_{3}\right) \mathrm{CH}_{2} \\
\mathrm{R}_{2}
\end{array}\right]_{2} \mathrm{O}}
\end{gathered}
$$

VI

$\mathrm{R}_{1}, \mathrm{R}_{2}=$ Alkyl or $\mathrm{H}$

the yields of enones were lower $(25 \sim 35 \%)$, and considerable amounts of by-products, presumed to be diallyl ether (VI) and allyl acetate (V), were produced by allylic rearrangement of the starting materials. A representative example of the synthesis of dienones is as follows. A mixture of 1 methyl-3-butyne-2-ol (I, $\mathrm{R}_{1}=\mathrm{R}_{2}=\mathrm{CH}_{3}, 1$ meq.), 2,2-dimethoxypropane $(2.5 \mathrm{meq})$, a catalytic amount of $85 \%$ phosphoric acid (1 drop) and acetic anhydride (1.4 meq) was heated with stirring in an autoclave at $130^{\circ} \mathrm{C}$ under a nitrogen atmosphere for $24 \mathrm{hr}$. The reaction 

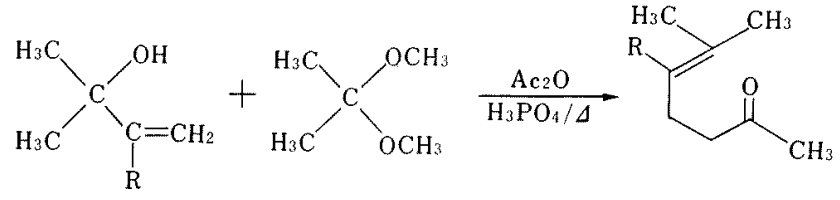

$$
\text { VII } \begin{aligned}
& \mathrm{a}, \mathrm{R}=\mathrm{H} \\
& \mathrm{b}, \mathrm{R}=\mathrm{CH}_{3}
\end{aligned}
$$

VIII $\mathbf{a}, \mathrm{R}=\mathrm{H}$

$\mathrm{b}, \mathrm{R}=\mathrm{CH}_{3}$
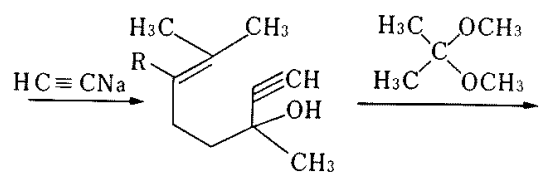

$\mathrm{IX} \quad \begin{aligned} & \mathrm{a}, \mathrm{R}=\mathrm{H} \\ & \mathrm{b}, \mathrm{R}=\mathrm{CH} 3\end{aligned}$<smiles>[R]C(C)=C(C)CCC(C)=CC=CC(C)=O</smiles>

$$
\begin{aligned}
& \text { a, } \mathrm{R}=\mathrm{H} \\
& \text { b, } \mathrm{R}=\mathrm{CH}_{3}
\end{aligned}
$$<smiles>[R]C1CCC(C)=C(/C=C/C(C)=O)C1(C)C</smiles>

$$
\begin{array}{ll}
\mathrm{a}, \mathrm{R}=\mathrm{H} \\
\mathrm{b}, \mathrm{R}=\mathrm{CH}_{3}
\end{array}
$$

mixture was neutralized with aqueous sodium bicarbonate solution and the resulting oil was washed with water and distilled under reduced pressure to afford 6-methyl-hepta-3,5-dien-2one (IV, $\mathrm{R}_{1}=\mathrm{R}_{2}=\mathrm{CH}_{3}$ ) in $60.2 \%$ yield. The merit of this method is that the reaction procedure can be carried out in a single operation and the product can be obtained by a simple process in fairly good yield.

Syntheses of ionone ${ }^{5)}$ and irone $^{6 /}$ were achieved by employing this procedure. As starting materials, substituted allyl alcohols $\left(\mathrm{VII}_{\mathrm{a}, \mathrm{b}}\right)$, were prepared by Grignard reaction of $\alpha, \beta$ unsaturated esters and methyl magnesium halide. ${ }^{7)}$ In the preparation of $\mathrm{VII}_{\mathrm{b}}$, the yield was greatly improved by changing the solvent from ether to tetrahydrofuran and the halide from methyl iodide or bromide to chloride. These results are summarized in Table I.

Pyrolysis of the alcohols and 2,2-dimethoxypropane by the previously described method afforded substituted heptenones ( VIII $_{a, b}$ ) in 23.9 and $33.4 \%$ yield, respectively. These heptenones were identical with authentic samples, prepared by rearrangement of the acetoacetate esters of the alcohols $\left(\mathrm{VII}_{\mathrm{a}, \mathrm{b}}\right)$. $^{8)}$ The enones $\left(\mathrm{VIII}_{\mathrm{a}, \mathrm{b}}\right)$ were ethynylated by the procedures of Kimel et al. ${ }^{91}$ to give dehydro linalool $\left(\mathrm{IX}_{\mathrm{a}}\right)$ and methyl dehydro linalool $\left(\mathrm{IX}_{\mathrm{b}}\right)$ in good yield. Syntheses of pseudoionone $\left(\mathrm{X}_{\mathrm{a}}\right)$ and pseudo-irone $\left(\mathrm{X}_{\mathrm{b}}\right)$ from dehydro linalool and methyl dehydro linalool were achieved by the same procedure as described

\begin{tabular}{|c|c|c|c|c|}
\hline Alkyl halide & Solvent & Reaction conditions & Yield & Notes \\
\hline $\mathrm{CH}_{3} \mathrm{I}$ & $\mathrm{Et}_{2} \mathrm{O}$ & reflux $/ 2 \mathrm{hr}$ & $60 \%$ & Ref. 7) \\
\hline $\mathrm{CH}_{3} \mathrm{Br}$ & $\mathrm{Et}_{2} \mathrm{O}$ & reflux $/ 2 \mathrm{hr}$ & $62 \%$ & \\
\hline & THF & $\begin{array}{l}30 \sim 40^{\circ} \mathrm{C} / 1 \mathrm{hr} \\
\text { reflux } / 1 \mathrm{hr}\end{array}$ & $81 \%$ & \\
\hline $\mathrm{CH}_{3} \mathrm{Cl}$ & THF & $\begin{array}{l}30 \sim 40^{\circ} \mathrm{C} / 1 \mathrm{hr} \\
\text { reflux } / 1 \mathrm{hr}\end{array}$ & $95 \%$ & \\
\hline
\end{tabular}
above in 62.5 and $58.2 \%$ yield, respectively.

TABLE I. 
These products were obtained as 5-cis and trans mixtures. Cyclization of the pseudocompounds by treatment with acetic acidsulfuric acid $(3: 7)^{10)}$ at $10 \sim 15^{\circ} \mathrm{C}$ for $30 \mathrm{~min}$ afforded $\beta$-ionone $\left(\mathrm{XI}_{\mathrm{a}}\right)$ and $\beta$-irone $\left(\mathrm{XI}_{\mathrm{b}}\right)$ almost exclusively, and these were isolated by steam distillation in good yields. The physical data for the prepared products were identical with the reported values.

\section{EXPERIMENTAL}

Gas-liquid chromatography was carried out with a Shimazu GC-3A unit.

\section{2,3'-Dimethyl-but-3-en-2-ol (VIrb)}

Into a solution of $\mathrm{MeMgCl}$, prepared by the passage of methyl chloride gas into $\mathrm{Mg}(12.0 \mathrm{~g}, 0.5 \mathrm{~g}$ atom) in anhydrous THF $(400 \mathrm{ml})$ with stirring until the $\mathrm{Mg}$ was completely dissolved, methyl methacrylate $(20 \mathrm{~g}, 0.2 \mathrm{M})$ in THF $(100 \mathrm{ml})$ was added dropwise at $30 \sim 40^{\circ} \mathrm{C}$ during the course of $1 \mathrm{hr}$. After the addition was complete, the mixture was stirred under reflux for $1 \mathrm{hr}$. The reaction mixture was poured into an aqueous solution of $\mathrm{NH}_{4} \mathrm{Cl}$ and $\mathrm{HCl}$ and extracted with ether. The extract was dried over $\mathrm{Na}_{2} \mathrm{SO}_{4}$. Fractional distillation gave a pure product $(19.0 \mathrm{~g}, 95 \%$ yield $)$. bp $115^{\circ} \mathrm{C} / 760 \mathrm{mmHg}$, literature. ${ }^{7}$ Glpc: $\mathrm{SE}-30.50^{\circ} \mathrm{C}$ $1 \mathrm{~atm}(\mathrm{He})$ retention time $\left(t_{R}\right) 5.3 \mathrm{~min}$. bp $115 \sim 116^{\circ} \mathrm{C} /$ $760 \mathrm{mmHg}$.

\section{6-Methyl-hept-5-en-2-one ( IIIIa)}

A mixture of 2-methyl-but-3-en-2-ol ( $30 \mathrm{~g}, 0.35$ mole), 2,2-dimethoxypropane (DMP, $92 \mathrm{~g}, 1.0$ mole), $85 \%$ phosphoric acid $\left(\mathrm{H}_{3} \mathrm{PO}_{4}, 1 \mathrm{drop}\right)$ and acetic anhydride $\left(\mathrm{Ac}_{2} \mathrm{O}, 51 \mathrm{~g}, 0.5\right.$ mole) was heated to $130 \sim 140^{\circ} \mathrm{C}$ with stirring in an autoclave under a nitrogen atmosphere for $16 \mathrm{hr}$. The reaction mixture was neutralized with excess $\mathrm{NaHCO}_{3}$ and the residual oil was dried over $\mathrm{Na}_{2} \mathrm{SO}_{4}$. Yields of products were determined by glpc analysis, and the data are as follows. Column, SE-30: temperature, $80^{\circ} \mathrm{C} ; 1.1 \mathrm{~atm}(\mathrm{He})$ starting material: retention time $\left(t_{R}\right) \mathrm{min}, 19.8 \mathrm{~g}, 6$-methyl-hept-5-en-2one: $t_{R} 10.5 \mathrm{~min}, 3.7 \mathrm{~g}, 23.9 \%$ and other by-products; $t_{R} 6.7 \mathrm{~min}$ and $13.6 \mathrm{~min}$. Authentic enone was prepared by rearrangemen ${ }^{81}$ of the acetoacetate derivative of the allyl alcohol.

\section{5,6-Dimethyl-hept-5-en-2-one-(VIIIb)}

The same procedure and scale as in the above experiment were employed. The yield of this enone was $33.4 \%$, as determined by glpc analysis $\left(t_{R} 10.5 \mathrm{~min}\right.$, column SE-30, $1 \mathrm{~atm}(\mathrm{He})$, temperature, $100^{\circ} \mathrm{C}$ ).

\section{Pseudo-ionone $(X a)$}

Dehydrolinalool (IXa) was prepared as described by Kimel et al.,9] and the physical properties were completely identical with those reported. A mixture of dehydrolinalool ( $5 \mathrm{~g}, 0.033$ mole), DMP ( $8 \mathrm{~g}, 0.09$ mole), $\mathrm{H}_{3} \mathrm{PO}_{4}$ (1 drop) and $\mathrm{Ac}_{2} \mathrm{O}$ ( $5 \mathrm{~g}, 0.05$ mole), was heated with stirring at $180^{\circ} \mathrm{C}$ for $1 \mathrm{hr}$ and then at $140^{\circ} \mathrm{C}$ for $14 \mathrm{hr}$. The reaction mixture was treated with the same manner as described above. Yield was determined by glpc analysis; starting material $(1.54 \mathrm{~g})$, $t_{R} 1.6 \mathrm{~min}, 5$-cis and trans-pseudo-ionone $(2.73 \mathrm{~g}$, $62.5 \%), t_{R} 6.7$ and $7.9 \mathrm{~min}$, column OV-17,60 180 ${ }^{\circ} \mathrm{C}$ $\left(10^{\circ} \mathrm{C} / \mathrm{min}\right), 1 \mathrm{~atm}\left(\mathrm{~N}_{2}\right)$. Silica gel chromatography afforded the starting material $(1.2 \mathrm{~g})$ and pseudo-ionone $(2.1 \mathrm{~g}, 49.3 \%)$. The formation of other by-products was almost negligible. Physical properties were identical with those of an authentic sample prepared by the procedure described by Saucy et al. ${ }^{11}$

\section{Pseudo-irone $(X b)$}

Metbyl dehydro linalool (IXb) was prepared according to Reference. ${ }^{93}$ Exactly the same scale and procedure was employed as the case of pseudo-ionone synthesis. The yield of pseudo-irone was $58.2 \%$ and the recovered starting material amounted to $1.36 \mathrm{~g}$, as determined by glpc analysis. Silica gel chromatography afforded pseudo-irone $(2.0 \mathrm{~g}, 47.6 \%)$ and starting material $(1.6 \mathrm{~g})$. The physical properties were completely identical with those of an authentic sample.

\section{REFERENCES}

1) a) G. Saucy and R. Marbet, Helv. Chim. Acta, 50, 1158 (1967).

b) R. Marbet and G. Saucy, Chimia, 14, 362 (1960).

c) A. Sturzengger, U. S. Patent, 2861109 (1958).

2) a) G. Saucy and R. Marbet, Hell. Chim. Acta, 50, 2091 (1967).

b) R. Marbet and G. Saucy, ibid., 50, 2095 (1967).

3) W. S. Johnson, L. Werthemann, W. R. Bartlett, T. L. Brockson, T. T. Li, D. J. Faulkner and M. R. Peterson, J. Amer. Chem. Soc., 92, $741(1970)$.

4) D. J. Faulkner, Synthesis, 1971, 175.

5) a) W. Kimel, N. W. Sax, S. Kaiser, G. G. Eichmann, G. O. Chase, and A. Ofner, $J$. Org. Chem., 23, 153 (1958).

b) W. Kimel, J. D. Surmatis, J. Weber, G. O. Chase, N. W. Sax and A. Ofner, ibid., 22, 1611 (1957).

c) A. Sturzenegger, J. Zelauskas and A. Ofner, ibid., 28, 920 (1963).

d) K. Suga and S. Urma, Reports of the Depart- 
ment of Technology of Chiba University, 14, 47 (1963).

6) a) B. A. Killy and F. B. Kipping, J. Chem. Soc., $1939,435$.

b) L. Ruzicka, Helv. Chem. Acta, 30, 1810 (1947); idem, ibid., 23, 959 (1940).

c) Y. R. Naves, A. V. Grampoloff and P. Bachmann, ibid., 30, 1599 (1947); idem, ibid., 30, 2221 (1947); idem, ibid., 32, 1798 (1949).

d) Firmenich \& Co., B. Patent, 643353 (1950); idem, Swiss Patent, 262269 (1949); idem, Swiss Patent, 267856 (1950).

e) Y.R. Naves, U. S. Patent, 2517800.

f) G. Merling, Ber., 41, 2064 (1908).

g) L. Ruzicka and H. Schinz, Helv. Chim. Acta, 23, 959 (1940).

h) V. N. Belov, N. A. Daev, S. D. Kustova, K. V. Leets, S. S. Poddubnaya, N. I. Skvortsova E. I. Shepelenkova and A. K. Shumeiki, J. Gen. Chem. U. S. S. R., 27, 1465 (1957) [C. A., 53, 4336c (1959)].

i) A. A. Petrov, ibid., 28, 1490 (1958); K. V. Leets, ibid., 28, 1846 (1958).

j) A. Rouve and M. Stoll, Helv. Chim. Acta, 33, 2019 (1950).

k) Y. R. Naves, P. Ardizio and P. Bachmann, Bull. Soc. Chim. France, 1950, 678; Helv. Chim. Acta, 34, 411 (1951).

l) W. Kimel, J. D. Surmatis, J. Weber, G. O. Chase, N. W. Sax and A. Ofner, J. Org. Chem., 22, 1611 (1957); idem, ibid., 23, 152 (1958).

m) H. Grütter, R. Helg and H. Schinz, Helv. Chim. Acta, 35, 771 (1952).

n) H. Eschinazi, J. Amer. Chem. Soc, 81, 2905 (1959).

o) M. Stoll and B. Willhalm, Helv. Chim. Acta, 35, 775 (1952); D. H. R. Barton, J. Chem. Soc., 1960, 271.

p) ABRAC, Belg. Patent, 616032 (1962) [C. A., $\mathbf{5 8}, 1500(1964)]$ q) E. H. Eschinazi (Givaudan \& Co.), U.S. Patent, 3019265 (1962); idem, U. S. Patent, 3019264 (1962); Hs. H. Günthard, C. F. Seidel and L. Ruzicka, Helv. Chim. Acta, 35, 1820 (1952); C. F. Seidel and L. Ruzicka, ibid., 35, 1826 (1952).

r) K. Seitz, Hs. H. Günthard and O. Jeger, ibid., 33, 2196 (1950).

s) Y.R. Naves, P.E.O.R., 41, 121 (1950); Y. R. Naves and P. Bachmann, Helv. Chim. Acta, 32, 599 (1949); idem, ibid., 32, 618 (1949); L. Ruzicka, H. Schinz, C. F. Seidel and Ch. Tavel, ibid., 30, 1810 (1947); Y. R. Naves, A. V. Grampoloff and P. Bachmann, ibid., 30, 599 (1947); idem, ibid., 31, 893 (1948); idem, ibid., 31, 1876 (1948).

t) D. Felix and M. Stoll, Chimia, 18, 174 (1964); idem, F. Patent, 1393451 (1965).

u) E. H. Eschinazi and M. L. Cotter, Tetrahedron, 20, 3481 (1964).

7) a) I. N. Rozhkov and S. M. Makin, Zhur. Obshch. Khim., 34, 59 (1964) [C.A., 60, 10576 b (1964)].

b) F. H. Owens, W. L. Myers and F. E. Zimmerman, J. Org. Chem., 26, 2288 (1961).

c) A. I. Lebedeva and E. D. Vainrub, Zhur. Obsheh. Khim., 22, 1974 (1952) [C. A., 47, 8640d (1953)]; idem, ibid., 26, 2436 (1956) [C. A., 51, 4967a (1956)].

8) W. Kimel, J. D. Surmatis, J. Weber, G. O. Chase, N. W. Sax and A. Ofner, J. Org. Chem., 22, 1611 (1957); idem, 23, 153 (1958); idem, U. S. Patent, 2795617 ; idem, U. S. Patent, 2628250; idem, U. S. Patent, 2638484.

9) W. Kimel, J. D. Surmatis, J. Weber, G. O. Chase, N. W. Sax and A. Ofner, J. Org. Chem., 22, 1611 (1957); idem, B. Patent, 788301; J. D. Surmatis, U. S. Patent, 2848502; W. Dott, Ger. Patent, 10177; I. N. Nagarov, Zhur. Obshch. Khim., 28, 1444 (1958).

10) E. E. Royals, Ind. Eng. Chem., 38, 546 (1946). 